\title{
Chamaecostus subsessilis and Chamaecostus cuspidatus (Nees \& Mart) C.Specht and D.W.Stev as Potential Sources of Anticancer Agents
}

Ezequias Pessoa de Siqueira ${ }^{*}$, Jonas Pereira Ramos ${ }^{2}$, Carlos Leomar Zani', Albina Carvalho de Oliveira Nogueira ${ }^{3}$, David Lee Nelson ${ }^{4}$, Elaine Maria de Souza-Fagundes ${ }^{2}$ and Betania Barros Cota $^{1}$

${ }^{1}$ Laboratory of Chemistry and Natural Products, René Rachou Research Center - FIOCRUZ, Belo Horizonte, MG, Brazil

${ }^{2}$ Department of Physiology and Biophysics, Federal University of Minas Gerais, Belo Horizonte, MG, Brazil

${ }^{3}$ Zoo-Botanic Foundation of Belo Horizonte, Belo Horizonte, MG, Brazil

${ }^{4}$ Pro-Rectory of Graduate and Research Program, Federal University of Jequitinhonha and Mucuri Valley, Diamantina, MG, Brazil

\begin{abstract}
Cytotoxicity activities of the crude ethanol extracts from Chamaecostus subsessilis and Chamaecostus cuspidatus and the fractions obtained by liquid-liquid partition were observed when these species were assayed against a panel of six human cancer cell lineages (HL60, Jurkat, MDA-MB231, MCF-7, HCT, THP-1) and normal (Vero) cells using the MTT colorimetric assay. The cytotoxic effects in the HL60, Jurkat and THP-1 lineages were mediated via an apoptotic mechanism when treated with crude ethanol extracts from these species. The presence of flavonoids, terpenoids and saponins in fractions from both species was observed in the preliminary phytochemical study. These results provide scientific support for the study of the Costaceae family and show that $C$. cuspidatus and $C$. subsessilis are potential sources of compounds with anticancer activities.
\end{abstract}

Keywords: Natural products; Chamaecostus; Cancer; Antitumoral agents

\section{Introduction}

The National Cancer Institute estimated that approximately $1,658,370$ new cases of cancer will be diagnosed in the United States in 2015 and 589,430 people will die from the disease. The projection is that breast cancer, lung and bronchus cancer, prostate cancer, colon and rectum cancer, bladder cancer, melanoma of the skin, nonHodgkin lymphoma, thyroid cancer, kidney and renal pelvic cancer, endometrial cancer, leukemia, and pancreatic cancer will be the most common cases.

Although research in cancer has advanced significantly in the last few decades and many of the mechanisms of action of cancer are already understood, in special the degenerative process caused for free radicals, cancer is a disease that still kills thousands of people worldwide. According to the statistics regarding cancer in the USA, approximately $1,658,370$ new cases will occur in 2015 , and 589,430 people will die from the disease [1].

In this context, the discovery of new drugs must be effective because these drugs may present mechanisms of action to prevent the recurrence of cancers.

Natural products (NPs) have been relevant to the development of drugs, particularly in the field of infectious diseases and cancer [2]. The structural complexity of molecules derived from NPs provides selective ligands for disease-related targets, disrupting the normal pathway of the molecular mechanism of the disease [3]. Thus, drugs derived from NPs present potential advantages over purely synthetic forms.

In the study of bioactive compounds, heterocyclic have fundamental importance as source of anticancer molecules, as example, CoumarinFused 1,4-Thiazepines, 2H-Chromenes derivatives, and 1-(5-aryl-1,3,4oxadiazol-2-yl)-1-(1H-pyrrol-2-yl) methanamines [4-6], substances that showed anticancer properties. Because of the extreme level of structural complexity associated, the cost of producing these drugs by purely synthetic strategies would be very high if the pure enantiomeric forms are essential for activity, thus natural products can be a source of new molecules to fulfill this role.

Our research group in NPs has been researching bioactive substances originating from secondary metabolites from several sources, such as plants, fungi, bacteria and marine organisms, in search of active principles against cancer and other diseases. We report here the results of the cytotoxic activities of the plants of the Chamaecostus genus - C. subsessilis and C. cuspidatus - against six cancer cell lines.

Several species of plants of the Costaceae family have traditionally been consumed because of their biological activities. The rhizomes of several plant species of the Costaceae family have been traditionally used as antiseptic, diuretic and detoxifying agents, as well as for the treatment of infections and inflammatory diseases [7-10] and the Costus genus has been described in folk medicine in Brazil for the treatment of "loose urine", genitourinary disorders and inflammations, hepatitis and pain in the liver, bruises and swelling, hernias, anemia, fever and eye irritation [11-14].

Some of the Costaceae species have been used in folk medicine for the treatment of infection diseases in Brazil. The mucilaginous juice of Costus scaber Ruiz and Pav (Syn.: C. anachiri Jacq.) is used as a febrifuge and for nephritic pain and gonorrhea [15]. Tea prepared from the whole Costus spiralis Roscoe plant, popularly known as 'canado-brejo' or 'cana-de-macaco', is used as a diuretic in diseases of the urinary tract and as a anti-syphilitic agent [16-19].

Although the pharmacological activities of Costus have been described in the literature, few studies of the properties of the Chamaecostus genus exist. Our studies provide support for isolation of the active principles of these species and the mechanism of action of these substances against cancer cells.

*Corresponding author: Ezequias Pessoa de Siqueira, René Rachou Research Center, Oswaldo Cruz Foundation, Av. Augusto de Lima, 1715, Barro Preto, Belo Horizonte, MG, 30190-002, Brazil, Tel: +553133497791; Fax: +553132953115; E-mail: ezequias@cpqrr.fiocruz.br

Received February 02, 2016; Accepted February 12, 2016; Published February 19, 2016

Citation: Siqueira EP, Ramos JP, Zani CL, Nogueira ACO, Nelson DL, et al. (2016) Chamaecostus subsessilis and Chamaecostus cuspidatus (Nees \& Mart) C.Specht and D.W.Stev as Potential Sources of Anticancer Agents. Nat Prod Chem Res 4 204. doi:10.4172/2329-6836.1000204

Copyright: (c 2016 Siqueira EP, et al. This is an open-access article distributed under the terms of the Creative Commons Attribution License, which permits unrestricted use, distribution, and reproduction in any medium, provided the original author and source are credited. 


\section{Materials and Methods}

\section{Collection of plant materials}

The Belo Horizonte Zoo-Botanical Foundation (BHZB) at Belo Horizonte, Minas Gerais, Brazil, provided the fresh and healthy rhizomes of the Chamaecostus cuspidatus and Chamaecostus subsessilis plants. A voucher specimen of each species was deposited at the Herbarium: Chamaecostus cuspidatus (Nees \& Mart.) C. Specht \& D.W.S. (BHZB 5582), Chamaecostus subsessilis (Nees \& Mart.) C. Specht \& D.W.S. (BHZB 8018).

\section{Preparation of crude ethanol extract from rhizomes}

Pure water was used to wash the rhizomes, and they were allowed to dry at room temperature. The fresh plant material was chopped into small pieces of about $5 \times 5 \mathrm{~cm}^{2}$ and extracted three times with absolute ethanol at room temperature with three-day periods of rest between extractions (748 g C. subsesilis rhizomes and 233 g C. cuspidatus rhizomes). The suspensions were filtered through cellulose filter paper, and the ethanol was evaporated under reduced pressure at $40^{\circ} \mathrm{C}$ using a rotary evaporator, yielding $7.3 \mathrm{~g}$ of crude ethanol extract from $C$. subsesilis (1\%) and $2.3 \mathrm{~g}$ of crude ethanol extract from C. cuspidatus (1\%) respectively.

\section{Preparation of fractions by liquid-liquid partition}

Crude ethanol extract was dissolved in methanol: water $(80: 20 \mathrm{v} / \mathrm{v})$ and sequentially partitioned with solvents of increasing polarity: hexane (HEX), dichloromethane (DCM), chloroform $\left(\mathrm{CHCl}_{3}\right)$, ethyl acetate (EtOAc) and water (AQ). The fractions were evaporated to dryness in a vacuum centrifuge evaporator. The weights and yields based on crude ethanol extracts were: (HEX) - $0.42 \mathrm{~g},(5.7 \%)$ for C. subsessilis and 0.42 $\mathrm{g}$, (18.3\%) for C. cuspidatus; (DCM) - $1.14 \mathrm{~g}$, (15.6\%) for C. subsessilis and $0.17 \mathrm{~g},(7.4 \%)$ for C. cuspidatus; $\left(\mathrm{CHCl}_{3}\right)-2.00 \mathrm{~g},(27.4 \%)$ for $\mathrm{C}$. subsessilis and $0.04 \mathrm{~g}$ (1.7\%) for C. cuspidatus; (EtOAc) - $0.40 \mathrm{~g}$, (5.5\%) for C. subsessilis and $0.12 \mathrm{~g}$, (5.6\%) for C. cuspidatus; (AQ) - $3.0 \mathrm{~g}$ (41.1\%) for C. subsessilis and $1.3 \mathrm{~g}$, (56.5\%) for C. cuspidatus.

\section{In-vitro Cytotoxicity Assays}

\section{Human cancer cell lines}

Six cancer cell lines were used; Jurkat (human immortalized line of T lymphocyte), HL60 (human promyelocytic leukemia), THP-1 (acute monocytic), MCF-7 and MDA-MB231 (breast cancer) and HCT-116 (colorectal carcinoma). The Vero lineage (African green monkey kidney cells) was used as a model for normal cells. All lineages were maintained in the logarithmic phase of growth in RPMI 1640 or D-MEM medium supplemented with $100 \mathrm{IU} / \mathrm{mL}$ penicillin and $100 \mu \mathrm{g} /$ $\mathrm{mL}$ streptomycin enriched with $2 \mathrm{mM}$ of L-glutamine. Leukemia cells were cultured in RPMI and 10\% foetal bovine serum. The adherent cells were maintained in D-MEM enriched with $5 \%$ foetal bovine serum. All cultures were maintained at $37^{\circ} \mathrm{C}$ in a humidified incubator with $5 \%$ $\mathrm{CO}_{2}$ and $95 \%$ air. The media were changed twice weekly and the cells were examined regularly. All cell lines were used for 20 passages.

\section{Evaluation of cytotoxic effect against human cancer cell lines}

Cell lineages were inoculated using $1 \times 10^{4}$ cells $(\mathrm{MCF}-7$, HCT, MDA-MB-231 and Vero), $5 \times 10^{4}$ cells (HL60) and $1 \times 10^{5}$ cells (Jurkat and THP-1) per well. The plates were pre-incubated for $24 \mathrm{~h}$ at $37^{\circ} \mathrm{C}$ to allow adaptation of cells prior to the addition of the test compounds. All extracts (crude ethanol extract and partitioned fractions) were dissolved in DMSO prior to dilution. The half-maximum inhibitory concentration $\left(\mathrm{IC}_{50}\right)$ was determined over a range of concentrations (eight nonserial dilutions from 100 to $1.5 \mu \mathrm{g} / \mathrm{mL}$ ). All cell cultures were incubated in a $5 \% \mathrm{CO}_{2} / 95 \%$ air humidified atmosphere at $37^{\circ} \mathrm{C}$ for $48 \mathrm{~h}$. The negative control included treatment with $0.5 \%$ DMSO. Cell viability was estimated by measuring the rate of mitochondrial reduction of tetrazolium dye (MTT). All the samples were tested in triplicate in three independent experiments [20]. The selectivity index (SI) was defined as the ratio of the $\mathrm{IC}_{50}$ observed in Vero cells to the $\mathrm{IC}_{50}$ observed in the experiment with cancer cells for the same substance tested. Etoposide was evaluated under the same experimental conditions as the positive control.

\section{DNA fragmentation assay}

Propidium iodide (PI) staining was employed to determine the cell cycle status and for quantification of DNA fragmentation (hypo diploid DNA-content) to determine the mechanism of cellular death by apoptosis [21]. Cells were treated with the samples (crude ethanol extract and partitioned fractions) at a concentration of $20 \mu \mathrm{g} / \mathrm{mL}$ in a humidified $5 \% \mathrm{CO}_{2} / 95 \%$ air atmosphere at $37^{\circ} \mathrm{C}$ for $24 \mathrm{~h}$. After incubation, the cells were centrifuged and ressuspended in hypotonic fluorochrome solution (HFS; $50 \mu \mathrm{g} / \mathrm{mL}$ PI in $0.1 \%$ sodium citrate plus $0.1 \%$ Triton X-100). The samples in HFS were incubated at $4^{\circ} \mathrm{C}$ during $4 \mathrm{~h}$ and immediately analyzed by flow cytometry. The PI fluorescence of 20,000 individual nuclei was measured using a FACScalibur flow cytometer. Data were analyzed using FlowJo ${ }^{\circledR}$ software (TreeStar Inc.).

The $\mathrm{IC}_{50}$ values for cytotoxicity activity were determined using Prism $5.0^{\circ}$ (GraphPad Software Inc.). Data were presented as medians and $95 \%$ confidence intervals. Statistical differences between the treatments and the control were evaluated by ANOVA. To express the DNA content, each data point represented the mean \pm SD from at least two independent experiments performed in duplicate. Statistical differences between the treatments and the control were evaluated by ANOVA, followed by the Bonferroni test $(\mathrm{P}>0.05)$.

\section{Phytochemical screening}

All the fractions from C. cuspidatus and C. subsessilis were analyzed for the presence of the principal natural products classes by Thin Layer Chromatography (TLC) on Silica gel G- $60 / \mathrm{F}_{254}$ plates $(0.25 \mathrm{~mm}$, Merck, Darmstadt, Germany) using the appropriate solvents for elution and visualization by UV absorbance or by spraying with developing reagents. The presence of alkaloids, antraquinones, cardiotonic heterosides, cumarins, flavonoids, terpenoids and saponines was determined using the specific reagents [22].

\section{Results and Discussion}

\section{Cytotoxic activity of the crude ethanol extracts and partitioned fractions}

Analyzing the behavior of the Vero cell (used as the control for toxicity) it was noticed that this cell was a little more sensitive against crude ethanol extract from $C$. subsessilis than crude ethanol extract from C. cuspidatus $\left(\mathrm{IC}_{50} 40.8 \pm 5.6\right.$ vs. $52.5 \pm 6.4$ ). This cell was more sensitive against fractions from C. subsesseilis than C. cuspidatus, $\mathrm{IC}_{50}$ ranging from $18.8 \pm 1.4$ to $48.6 \pm 9.7 \mu \mathrm{g} / \mathrm{mL}$ and $52.5 \pm 6.4$ to $96.4 \pm$ $14.9 \mu \mathrm{g} / \mathrm{mL}$, respectively. Aqueous fractions (AQ) did not show activity against this cell.

Crude ethanol extract from C. subsessilis was active against all cancer cell lines tested, $\mathrm{IC}_{50}$ ranging from $8.2 \pm 0.2$ (Jurkat) to $53.8 \pm$ 0.7 (MCF-7) and the lines Jurkat, HL-60 and THP-1 were the most sensitive. The crude ethanol extract from C. cuspidatus was not active 
against MCF-7 nor HCT-116 $\left(\mathrm{IC}_{50}>100 \mu \mathrm{g} / \mathrm{mL}\right)$. This observation segregates the species on the basis of potency against this lineage.

In general, all fractions were active against the lines tested, exception AQ fraction from both species, that was inactive. The MDAMB231 cell line was sensitive against no fraction from C. cuspidatus.

The main parameter in the biological evaluation of a natural product is the toxicity that the substance presents for normal cells. Active substances will no longer be good targets for the development of new drugs when they present toxicity levels for normal cells of the same order of magnitude as that presented for the therapeutic targets. In other words, good candidates for the development of new drugs will be those that present high selectivity indices (SI) and low values of $\mathrm{IC}_{50}$.

\section{Preliminary phytochemical analysis}

It is important to mention that the TLC technique is only predictive on the existence or not of a compound/chemical class, the results indicate possible presence. All the fractions from C. cuspidatus and C. subsessilis were screened for alkaloids, antraquinones, cardiotonic heterosides, cumarins, flavonoids, terpenoids and saponins. Flavonoids were present in chloroform- and ethyl acetate-soluble fractions from C. subsessilis and ethyl acetate-soluble fraction from C. cuspidatus. Terpenoids were found in hexane- and dichloromethane-soluble fractions, whereas saponins were detected in water-soluble fractions from both plant species (Tables 1 and 2). According to the TLC profile, the activity was greatest in fractions of medium and low polarity, whereas no activity was detected in aqueous fractions. No alkaloids, antraquinones, cardiotonic heterosides, or cumarins were detected in any of all the fractions tested in preliminary phytochemical studies.

The hexane and dichloromethane fractions from both species could be used as good sources of compounds in the bio guided studies for the isolation of lead compounds. Terpenes and flavonoids may be the active constituents responsible for the antiproliferative activity in nonpolar fractions. However, there are few reports regarding the isolation of flavonoids and terpenes from Costaceae species. The triterpenes 31-norcycloartanone, cycloartanol, cycloartenol and cycloaudenol were isolated from Costus speciosus roots. Flavonol diglycosides and flavonoids were isolated from the leaves of Costus spicatus. In this same study, quercetin 3-O-neohesperidoside exhibited moderate inhibitory activity against nitric oxide production $\left(\mathrm{IC}_{50}\right.$ value of $\left.55 \mu \mathrm{M}\right)$ [23].

\section{Apoptosis evaluation of cytotoxic extracts from C. cuspidatus and C. subsessilis rhizomes by flow cytometry}

Crude ethanol extracts from C. cuspidatus and C. subsessilis were evaluated with respect to the pro-apoptotic activity against HL60, Jurkat and THP-1, the cell lines most susceptible to these samples. The extracts induced DNA fragmentation in all the lines at the concentration of $20 \mu \mathrm{g} / \mathrm{mL}$, with higher apoptotic activities than etoposide in these cell lines (Figure 1).

Cancer lines (HL-60, Jurkat and THP-1) were observed to be more sensitive to the treatment C. cuspidatus and C. subsessilis crude ethanol extracts. They had $\mathrm{IC}_{50}$ values in the same $20 \mu \mathrm{g} / \mathrm{mL}$ range, an SI greater than three and could be considered good candidates for the isolation of natural products [24-26]. In addition, these extracts presented proapoptotic activities, characterized by chromatin condensation and nuclear shrinkage, in the assays using PI, which binds to DNA after the plasma membrane, resulting in fluorescence that can be detected by flow cytometry.

Apoptosis is a programmed cell death that is disrupted in the tumorigenesis. At the concentration of $20 \mu \mathrm{g} / \mathrm{mL}$, pro-apoptotic effects of the crude ethanol extracts from C. cuspidatus and $C$. subsessilis could be observed in all the cell lines. These results support previous cytotoxic effects in the screening assays, suggesting that their anticancer properties can be mediated by apoptosis induction. Nadumane et al. (2011) demonstrated that the ethanol extract of Costus pictus is cytotoxic for HT-1080 fibrosarcoma cells at $120 \mu \mathrm{g} / \mathrm{mL}$ using the MTT assay, but it was nontoxic to the normal human lymphocytes

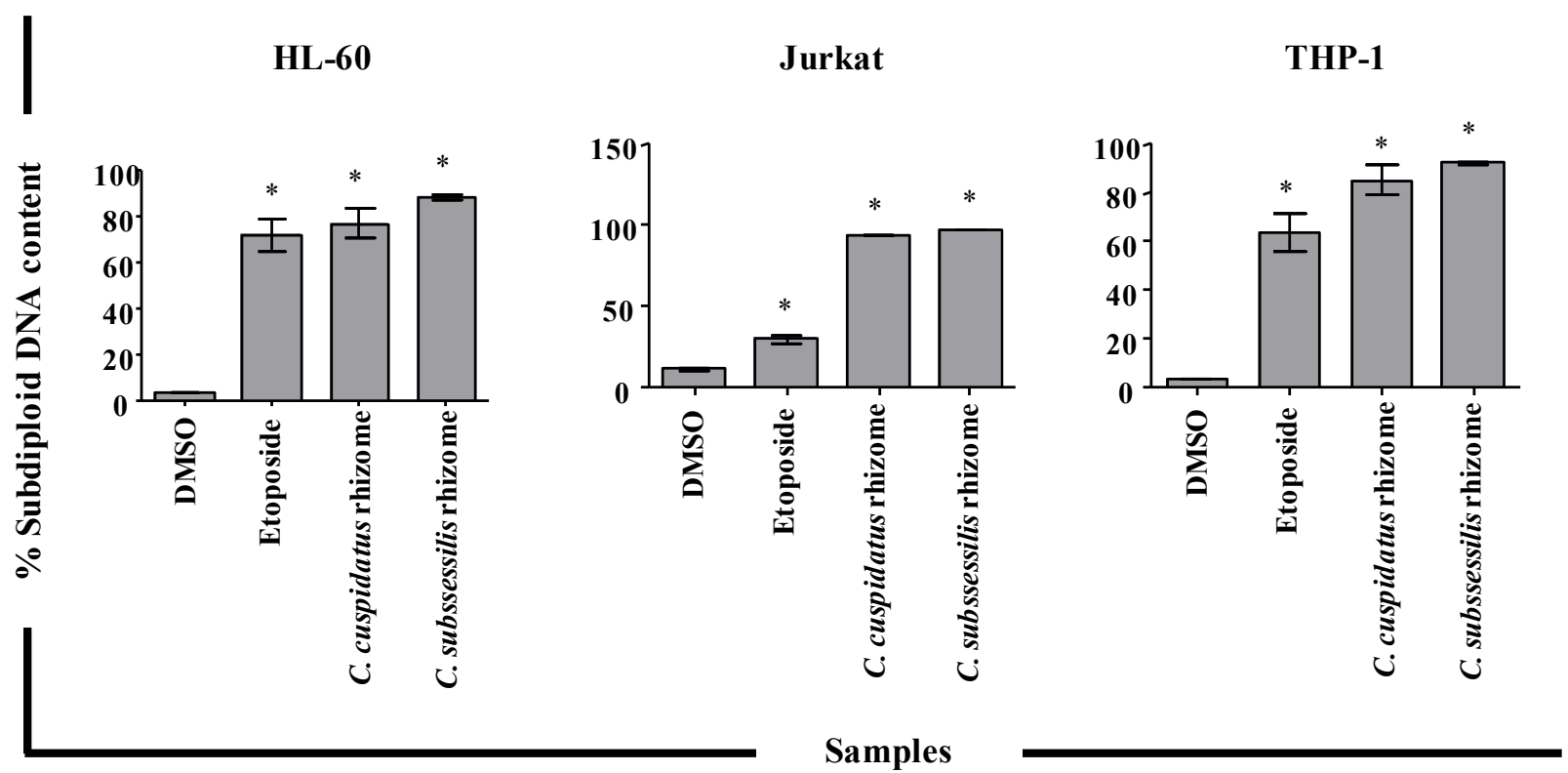

Figure 1: Effect of the extracts on the induction of fragmentation in leukemic cells. The cells were incubated with the compounds at the concentration of $20 \mu \mathrm{g} / \mathrm{mL}$ at $37^{\circ} \mathrm{C}$ in a $5 \% \mathrm{CO}_{2}$ atmosphere for $24 \mathrm{~h}$. DNA content was assessed by flow cytometric analysis of cells labeled with propidium iodide. Each data point represents the mean \pm SD from two independent experiments ( ${ }^{*} \mathrm{P}<0.05$ Student $\mathrm{T}$-test). Etoposide and ethanol extracts of $C$. cuspidatus and $C$. subsessilis rhizome were tested at a concentration of $20 \mu \mathrm{g} / \mathrm{mL}$. 
Citation: Siqueira EP, Ramos JP, Zani CL, Nogueira ACO, Nelson DL, et al. (2016) Chamaecostus subsessilis and Chamaecostus cuspidatus (Nees \& Mart) C.Specht and D.W.Stev as Potential Sources of Anticancer Agents. Nat Prod Chem Res 4: 204. doi:10.4172/2329-6836.1000204

Page 4 of 5

\begin{tabular}{|c|c|c|c|c|c|c|c|}
\hline \multirow[t]{2}{*}{ Plant extract } & \multicolumn{7}{|c|}{ Test strain IC $_{50}(\mathrm{ug} / \mathrm{mL}) / \mathrm{SI}$} \\
\hline & HL-60 & Jurkat & MDA-MB231 & MCF-7 & HCT-116 & THP-1 & VERO \\
\hline \multicolumn{8}{|l|}{ C. cuspidatus } \\
\hline Crude ethanol extract & $15.4 \pm 1.3 / 3.4$ & $16.3 \pm 0.4 / 3.2$ & $98.9 \pm 5.8 / 0.5$ & $>100.0 / \mathrm{nd}$ & $>100 /$ n.d. & $11.3 \pm 0.7 / 4.6$ & $52.5 \pm 6.4$ \\
\hline HEX & $4.7 \pm 2.6 />21.3$ & $2.9 \pm 1.1 />34.4$ & $>100.0 /$ n.d. & $45.7 \pm 18.1 />2.2$ & $8.3 \pm 1.7 />12.0$ & $36.3 \pm 9.8 />2.7$ & $>100.0$ \\
\hline DCM & $7.3 \pm 2.6 / 13.2$ & $2.2 \pm 0.2 / 43.8$ & $>100.0 /$ n.d. & $37.2 \pm 15.2 / 2.6$ & $7.3 \pm 4.3 / 13.2$ & $18.5 \pm 11.4 / 5.2$ & $96.4 \pm 14.9$ \\
\hline $\mathrm{CHCl}_{3}$ & $6.1 \pm 1.9 />16.4$ & $22.7 \pm 15.1 />4.4$ & $>100.0 /$ n.d. & $22.5 \pm 7.1 />4.4$ & $11.9 \pm 4.2 />8.8$ & $11.7 \pm 4.2 />8.5$ & $>100$ \\
\hline EtOAc & $25.4 \pm 9.4 />3.9$ & $35.3 \pm 11.5 />2.8$ & $>100.0 /$ n.d. & $>100.0 /$ n.d. & $27.9 \pm 4.7 />3.6$ & $>100.0 /$ n.d. & $>100.0$ \\
\hline $\mathrm{AQ}$ & $>100.0 /$ n.d. & $>100.0 /$ n.d. & $>100.0 /$ n.d. & $>100.0 /$ n.d. & >100.0/n.d. & $>100.0 /$ n.d. & $>100.0$ \\
\hline \multicolumn{8}{|l|}{ C. subsessilis } \\
\hline Crude ethanol extract & $8.3 \pm 1.5 / 4.9$ & $8.2 \pm 0.2 / 4.9$ & $32.6 \pm 0.3 / 1.3$ & $53.8 \pm 6.7 / 0.7$ & $18.4 \pm 1.4 / 2.2$ & $11.9 \pm 0.2 / 3.4$ & $40.8 \pm 5.6$ \\
\hline HEX & $9.3 \pm 0.5 / 5.2$ & $10.6 \pm 1.3 / 4.6$ & $5.5 \pm 2.8 / 8.8$ & $43.6 \pm 6.2 / 1.1$ & $17.3 \pm 1.2 / 2.8$ & $16.6 \pm 1,3 / 3.0$ & $48.6 \pm 9.7$ \\
\hline DCM & $4.7 \pm 0.2 / 6.8$ & $6.0 \pm 0.1 / 5.3$ & $9.2 \pm 1.9 / 3.4$ & $23.1 \pm 0.9 / 1.4$ & $9.6 \pm 1.0 / 3.3$ & $8.0 \pm 0.1 / 4.0$ & $31.9 \pm 5.9$ \\
\hline $\mathrm{CHCl}_{3}$ & $2.6 \pm 0.1 / 7.2$ & $4.2 \pm 0.1 / 4.5$ & $6.5 \pm 0.8 / 2.9$ & $14.5 \pm 0.2 / 1.3$ & $>100.0 /$ n.d. & $4.8 \pm 0.1 / 3.9$ & $18.8 \pm 1.4$ \\
\hline EtOAc & $4.7 \pm 0.8 / 6.0$ & $19.1 \pm 2.5 / 1.5$ & $13.8 \pm 2.7 / 2.1$ & $>100.0 /$ n.d. & $>100.0 /$ n.d. & $9.1 \pm 2.5 / 3.1$ & $28.4 \pm 0.9$ \\
\hline $\mathrm{AQ}$ & $>100.0 /$ n.d. & >100.0/ n.d. & $>100.0 /$ n.d. & $>100.0 /$ n.d. & $>100.0 /$ n.d. & $>100.0 /$ n.d. & $>100.0$ \\
\hline Control (Etoposide) & $1.8 \pm 0.7 />55.6$ & $>100.0 /$ n.d. & $>100.0 /$ n.d. & $>100.0 /$ n.d. & $>100.0 /$ n.d. & $2.1 \pm 1.2 / \mathrm{n} . \mathrm{d}$ & $>100.0$ \\
\hline
\end{tabular}

Table 1: Results of the cytotoxicity experiments of the crude ethanol extracts and partitioned fractions from $C$. cuspidatus and $C$. subsessilis against cancer cell lines. Highlighted results present the $\mathrm{IC}_{50}$ lower than $10 \mu \mathrm{g} / \mathrm{mL}$.

\begin{tabular}{|c|c|c|c|c|c|c|c|c|c|c|c|c|}
\hline \multirow[t]{3}{*}{ Chemical class } & \multicolumn{10}{|c|}{ Phytochemical result } & \multirow[t]{3}{*}{ Reagent } & \multirow[t]{3}{*}{ Solvent mixtures } \\
\hline & \multicolumn{5}{|c|}{ C. cuspidatus } & \multicolumn{5}{|c|}{ C. subsessilis } & & \\
\hline & HEX & DCM & $\mathrm{CHCl}_{3}$ & EtOAc & $A Q$ & HEX & DCM & $\mathrm{CHCl}_{3}$ & EtOAc & $A Q$ & & \\
\hline Alkaloids & - & - & - & - & - & - & - & - & - & - & Dragendorff & $\begin{array}{c}\mathrm{CHCl}_{3} \mathrm{MeOH}: \text { Diethylamine }(50: 40: 10 \\
\text { v/v) }\end{array}$ \\
\hline Antraquinones & - & - & - & - & - & - & - & - & - & - & Potassium hydroxide & DCM $(100 \%)$ \\
\hline $\begin{array}{l}\text { Cardiotonic } \\
\text { heterosides }\end{array}$ & - & - & - & - & - & - & - & - & - & - & Kedde & EtOAc:MeOH: $\mathrm{H}_{2} \mathrm{O}(80: 20: 5 \mathrm{v} / \mathrm{v})$ \\
\hline Cumarins & - & - & - & - & - & - & - & - & - & - & Potassium hydroxide & DCM (100\%) \\
\hline Flavonoids & - & - & - & + & - & - & - & + & + & - & NP/PEG & $\begin{array}{c}\text { EtOAc: } \mathrm{MeOH}: \mathrm{H}_{2} \mathrm{O}: \mathrm{AcOH} \\
(80: 20: 5: 0.1 \mathrm{v} / \mathrm{v})\end{array}$ \\
\hline Terpenoids & + & + & - & - & - & + & + & - & - & - & $\begin{array}{l}\text { Liebermann- } \\
\text { Burchard }\end{array}$ & DCM: MeOH (95:5 v/v) \\
\hline Saponins & - & - & - & + & + & - & - & - & - & + & $\begin{array}{l}\text { Vanillin-sulphuric } \\
\text { acid }\end{array}$ & EtOAc:MeOH: $\mathrm{H}_{2} \mathrm{O}(80: 20: 5 \mathrm{v} / \mathrm{v})$ \\
\hline
\end{tabular}

Table 2: Phytochemical investigation of the crude ethanol extracts and fractions from C. cuspidatus and C. subsessilis.

by the trypan blue dye exclusion method [8]. This extract also induced apoptosis in the fibrosarcoma cells. In another study, the methanol extract of the from Costus pictus furnished chloroform- and methanolsoluble and methanol-insoluble fractions that were toxic to HT29 and A549 cells at concentrations ranging from 125 to $200 \mu \mathrm{g} / \mathrm{mL}$ [7].

\section{Conclusion}

To the best of our knowledge, this is the first time that anticancer studies for these plant species have been reported. The antiproliferativie effects of these plants can be linked to the induction of apoptosis. The antiproliferative effects of some fractions from C. cuspidatus and $C$. subsessilis were superior to those of the crude extract. Terpenes and flavonoids may be the active constituents of these species. The isolation and identification of the active metabolites in these extracts are currently under investigation in our laboratory.

\section{Acknowledgements}

The authors are grateful to the Fundação de Amparo à Pesquisa do Estado de Minas Gerais' (FAPEMIG) and the Fundação Oswaldo Cruz (FIOCRUZ) for financial support. DLN was the recipient of a PVNS fellowship from the Coordenação de Aperfeiçoamento de Pessoal de Ensino Superior (CAPES).

\section{References}

1. http://www.cancer.gov/about-cancer/what-is-cancer/statistics.

2. Cragg GM, Newman DJ (2013) Natural products: a continuing source of novel drug leads. Biochim Biophys Acta 1830: 3670-3695.
3. Clardy J, Walsh C (2004) Lessons from natural molecules. Nature 432: 829-837.

4. Khoobi M, Foroumadi A, Emami S, Safavi M, Dehghan G, et al. (2011) Coumarin-based bioactive compounds: facile synthesis and biological evaluation of coumarin-fused 1,4-thiazepines. Chem Biol Drug Des 78: 580-586.

5. Azizmohammadi $M$, Khoobi $M$, Ramazani $A$, Emami $S$, Zarrin A, et al. (2013) $2 \mathrm{H}$-chromene derivatives bearing thiazolidine-2,4-dione, rhodanine or hydantoin moieties as potential anticancer agents. Eur J Med Chem 59: 15-22.

6. Ramazani A, Khoobi M, Torkaman A, Nasrabadi FZ, Forootanfar H, et al. (2014) One-pot, four-component synthesis of novel cytotoxic agents 1-(5-aryl-1,3,4oxadiazol-2-yl)-1-(1H-pyrrol-2-yl)methanamines. Eur J Med Chem 78: 151-156.

7. Sathuvan M, Vignesh A, Thangam R, Palani P, Rengasamy R, et al. (2012) In vitro Antioxidant and Anticancer potential of Bark of Costus pictus D.DON Asian Pac J Trop Biomed 2: s741-s749.

8. Nadumane VK, Rajashekar S, Narayana P, Adinarayana S, Vijayan S, et al. (2011) Evaluation of the anticancer potential of Costus pictus on fibrosarcoma (HT-1080) cell Line. J Nat Pharm 2: 72-76.

9. Souza CD, Felfili JM (2006) Uso de plantas medicinais na região de Alto Paraíso de Goiás, GO, Brasil. Acta bot bras 20: 135-142.

10. Pilla MAC, Amorozo MCM, Furlan A (2006) Obtenção e uso das plantas medicinais no distrito de Martim Francisco, Município de Mogi-Mirim, SP, Brasil. Acta bot bras 20: 789-802.

11. Carneiro DB, Barboza MSL, Menezes MP (2010) Plantas nativas úteis na Vila dos Pescadores da Reserva Extrativista Marinha Caeté-Taperaçu, Pará, Brasil. Acta bot bras 24: 1027-1033.

12. Pinto EPP, Amorozo MCM, Furlan A (2006) Conhecimento popular sobre plantas medicinais em comunidades rurais de mata atlântica - Itacaré, BA Brasil. Acta bot bras 20: 751-762. 
Citation: Siqueira EP, Ramos JP, Zani CL, Nogueira ACO, Nelson DL, et al. (2016) Chamaecostus subsessilis and Chamaecostus cuspidatus (Nees \& Mart) C.Specht and D.W.Stev as Potential Sources of Anticancer Agents. Nat Prod Chem Res 4: 204. doi:10.4172/2329-6836.1000204

13. Boscolo OH, Senna LV (2008) Plantas de uso medicinal em Quissamã, Rio de Janeiro, Brasil. Iheringia Ser Bot 63: 263-277.

14. Costa VP, Mayworm MAS (2011) Plantas medicinais utilizadas pela comunidade do bairro dos Tenentes - município de Extrema, MG, Brasil. Rev Bras PI Med 13: 282-292.

15. Breitbach UB, Niehues M, Lopes NP, Faria JEQ, Brandão MGL (2013) Amazonian Brazilian medicinal plants described by C.F.P. von Martiusin the 19th century. J Ethnopharmacol 147: 180-189.

16. Coimbra R (1958) Notas de Fitoterapia. Catálogo dos Dados Principais sobre Plantas Utilizadas em Medicina e Farmácia. 2nd edn. Silva Araújo-Roussel (ed), Rio de Janeiro, Brazil. p: 159.

17. Cruz GL (1982) Dicionário de Plantas Úteis do Brasil. 2nd edn. Civilização Brasileira, S.A. Rio de Janeiro, Brazil. p: 573.

18. Corrêa MP (1984) Dicionário das Plantas Úteis Do Brasil e das Exóticas Cultiváveis, Imprensa Nacional, Instituto Brasileiro de Desenvolvimento Florestal, Rio de Janeiro, Brazil. p: 48

19. Araújo Viel T, Diogo Domingos $C$, da Silva Monteiro AP, Riggio Lima-Landman MT, Lapa AJ, et al. (1999) Evaluation of the antiurolithiatic activity of the extract of Costus spiralis Roscoe in rats. J Ethnopharmacol 66: 193-198.
20. Monks A, Scudiero D, Skehan P, Shoemaker R, Paull K, et al. (1991) Feasibility of a high-flux anticancer drug screen using a diverse panel of cultured human tumor cell lines. J Natl Cancer Inst 83: 757-766.

21. Riccardi C, Nicoletti I (2006) Analysis of apoptosis by propidium iodide staining and flow cytometry. Nat Protoc 1: 1458-1461.

22. Wagner H, Bladt S (1995) Plant Drug Analysis - A Thin Layer Chromatography Atlas. 2nd edn. Springer-Verlag, Berlin Heidelberg, New York, USA.

23. Da Silva BP, Bernardo RR, Parente JP (2000) Flavonol glycosides from Costus spicatus. Phytochemistry 53: 87-92.

24. Skehan P, Storeng R, Scudiero D, Monks A, McMahon J, et al. (1990) New colorimetric cytotoxicity assay for anticancer-drug screening. J Natl Cancer Inst 82: $1107-1112$.

25. Koch A, Tamez P, Pezzuto J, Soejarto D (2005) Evaluation of plants used for antimalarial treatment by the Maasai of Kenya. J Ethnopharmacol 101: 95-99.

26. Badisa RB, Darling-Reed SF, Joseph P, Cooperwood JS, Latinwo LM, et al. (2009) Selective cytotoxic activities of two novel synthetic drugs on human breast carcinoma MCF-7 cells. Anticancer Res 29: 2993-2996. 